\title{
Web Appendix: Parental Education and Offspring Outcomes: Evidence from the Swedish Compulsory School Reform
}

\author{
Petter Lundborg \\ Anton Nilsson \\ Dan-Olof Rooth
}

\begin{abstract}
This web appendix provides additional material to the paper "Parental Education
\end{abstract} and Offspring Outcomes: Evidence from the Swedish Compulsory School Reform." 


\section{Appendix A}

In this section we give a more detailed overview of the Swedish compulsory school reform. ${ }^{1}$ Section IIA in the paper provides a shorter and less detailed version of this text.

In the 1940s, prior to the implementation of the reform, children in Sweden were kept together in a common school (folkskolan) until either fourth or sixth grade. The arrangements differed from municipality to municipality but most often students stayed in the common school until sixth grade (SOU 1955:53). Individuals with sufficient grades were then selected for the three to five year long junior secondary school (realskolan), whereas individuals who were not selected for junior secondary school remained in the common school until compulsory schooling was completed. Compulsory schooling spanned seven years, or in some municipalities (mainly in the large cities) eight years. ${ }^{2}$

The Swedish educational system was deemed insufficient, however, and many other Western countries had already introduced eight or nine years of compulsory schooling, or were about to do so (Marklund 1980). Hence, there was growing political pressure for school reform throughout the 1940s and in 1948 a parliamentary committee delivered their proposal to introduce a new compulsory school, consisting of nine compulsory years.

Rather than being introduced across the country at the same time, it was decided that the school reform was to be implemented gradually across municipalities. The reason for this was to enable evaluations of the reform before a decision was taken whether or not to implement it nationwide. Beginning in 1949, the government, advised by the National Board of Education, selected 14 municipalities who were the first to implement the reform in that same year. These were selected out of 144 municipalities who had shown an interest in immediately introducing the reform. While no strict statistical criteria for the selection were used, there was an attempt to make sure that the implementing municipalities in this initial phase were representative of the country's population, both demographically and geographically (Marklund 1981).

More municipalities then implemented the reform year by year and the government continued to decide which municipalities, out of the ones who had shown an interest, were to implement the reform. In the decision process, factors such as the availability of teachers and school premises, population growth, and tax revenues, were taken into account. The reform

\footnotetext{
${ }^{1}$ This section builds extensively on Marklund (1980, 1981, 1982, 1985, 1987), where the reform is thoroughly described.

${ }^{2}$ As children in Sweden generally start school during the calendar year in which they turn seven, this means that compulsory schooling normally lasted until the age of 13 or 14 .
} 
was generally implemented by all school districts within the municipality, with the exception of the three big city municipalities of Stockholm, Göteborg and Malmö, where the reform was implemented in different parts of the municipalities at different times.

In 1962, the parliament decided that the reform should be implemented nation-wide. Municipalities were required to have the new system in place no later than in 1969, but the exact timing of the implementation was now in the hands of the municipalities themselves (Holmlund 2008).

Given this institutional background, it is clear that the timing of the reform implementation was not random. This has also been documented in previous papers using the reform, such as Meghir and Palme (2003), Holmlund (2008), and Holmlund, Lindahl and Plug (2008) who have shown that the reform was implemented earlier in municipalities with higher average income and education prior to the reform period. This is also what we find; municipalities with higher levels of educational attainment in the 1930s were prone to implement the reform earlier. ${ }^{3}$ These results point to the importance of correctly controlling for unobserved differences across municipalities.

Besides increasing the mandatory number of years of schooling from seven to nine, the reform implied some other changes to the school system. First, there were some changes in the way students were sorted. Whereas the old school system typically separated students based on their performance to different schools after sixth grade, the new system kept students together in the same school all the way up through ninth grade. In ninth grade, students in the new school system were to choose between a vocational track, a general track and an academic track. Schools would then stream students into classes according to the track chosen (Marklund 1980).

In practice, however, sorting according to ability took place before ninth grade also in the new system although students were now kept together in the same school. In particular, students were allowed to choose between different courses such as languages or vocational training in seventh and eighth grade, and from 1955 and onwards between easier and harder classes in some subjects such as Math. Most schools preferred to stream students into different classes according to their choices. Marklund (1987, p. 180) notes that "the reform school between 1955 and 1960 conformed to a streaming system that in terms of routes was not too much different from the old parallel school system with one common school route and

\footnotetext{
${ }^{3}$ Hjalmarsson, Holmlund and Lindquist (2011) also documented that parental education predicted reform participation, but this relationship vanished when municipality fixed effects and municipality-specific linear trends were controlled for.
} 
one junior secondary school route for students of this age". In 1962, the parliament decided to prohibit streaming before ninth grade, however (Marklund 1985). In Math and foreign languages, students would still be able to choose between harder or easier classes depending on their skills and preferences, but they would be kept together with their regular classmates in all other subjects.

Second, the reform meant a change to a national curriculum. In practice, however, the most important change to the curriculum appears to be that English became a compulsory subject in reform schools and was now taught from fifth grade (Holmlund 2008). ${ }^{4}$ English was not a compulsory subject in the old school system. Beginning in 1955, however, the same requirement was also introduced in non-reform schools. ${ }^{5}$

As with any reform that increases the mandatory years of schooling, the Swedish reform meant an additional resource burden on the reform municipalities. Among other things, the reform increased the demand for teachers. Partly as a result of large birth numbers, Sweden already experienced a lack of teachers beginning in the early 1950s and the reform contributed to this shortage. The situation was not severe in the sense that schools had to be closed or classes merged, but it led schools to hire more teachers that were not formally qualified (Marklund 1981). Several teachers colleges were however opened during the time period to counteract the shortage, which began to ease in the mid-1960s (Marklund 1981).

In order to compensate reform municipalities for the burden of hiring additional teachers and other expenses, the government allocated ear-marked resources. Moreover, means-tested

\footnotetext{
${ }^{4}$ Other than English, the change to a national curriculum did not imply any large changes to the total number of hours taught or to the number of hours allocated to different subjects (Marklund 1982). The introduction of English as a compulsory subject came at the expense of somewhat reduced teaching in Swedish as a first language (Marklund 1981). After 1955, there was a further expansion in the number of hours of English teaching in 6th grade, this time at the expense of History teaching, which was reduced by about one hour per week.

${ }^{5}$ The reform also implied some changes to the content of some subjects. If these changes somehow increased the quality of the courses taught, our IV estimates would capture both the effect of additional years of schooling and greater quality of schooling. There is little evidence that such changes in the curriculum would have any large impact on educational outcomes. Using the large variation in curriculum across U.S. high schools, Altonji (1995) finds no effect of curriculum on post-secondary education. Hall (2012) exploited a Swedish reform during the 90s that reduced the differences between academic and vocational tracks in upper secondary school through prolonging and increasing the academic content of the latter. The reform did not affect enrollment in university studies or subsequent earnings. In addition, the reform increased the probability of dropping out of school for low-performing students, which shows that changes to a high-level curriculum might even have negative effects on student performance. Alexander and Pallas (1984) found a positive effect of a new high school curriculum on cognitive performance but only among high-ability students.
} 
scholarships were used to compensate families for forgone earnings resulting from keeping their children longer in school in reform municipalities. There was also a universal child allowance introduced in 1948, providing support to children up to the age of 16 . These compensations directed to municipalities and families implied that reform implementation was not necessarily associated with a greater economic burden for municipalities and families. $^{6}$

This paper is not the first to exploit the Swedish compulsory schooling reform as a source of exogenous variation in schooling. Meghir and Palme (2005) established that the reform increased educational attainment and led to significantly higher labor incomes among individuals with low-educated fathers. Hjalmarsson, Holmlund and Lindquist (2011) and Meghir, Palme and Schnabel (2012) focused on crime. Holmlund, Lindahl and Plug (2011) used the reform to document evidence of a causal effect of parent's educational attainment on child's educational attainment.

Regarding health outcomes, Spasojevic (2010) used Swedish survey data and found some weak evidence that one year of additional schooling generated by the reform led to better selfreported health and a higher likelihood of having a BMI (body mass index) in the healthy range. Lager and Torssander (2012) documented that individuals exposed to the reform had a somewhat lower mortality risk after the age of 40. Meghir, Palme and Simeonova (2012) investigated hospitalizations as well as mortality among individuals aged 40 to 60 exposed to the reform but were not able to find significant effects on any of these outcomes. No previous study has examined the effects on health and skills among children of those who were exposed to the reform.

\section{REFERENCES}

Alexander, Karl L and Aaron M. Pallas. 1984. "Curriculum Reform and School Performance: An Evaluation of the New Basics." American Journal of Education 92 (4): 391-420.

Altonji, Joseph G. 1995. "The Effects of High School Curriculum on Education and Labor Market Outcomes." Journal of Human Resources 30 (3): 410-438.

Hall, Caroline. 2012. "The Effects of Reducing Tracking in Upper Secondary School:

\footnotetext{
${ }^{6}$ There were also some other reforms launched in Sweden during our study period. In the area of health care, the most important one was the universal health care coverage that was enacted in 1955. This reform was introduced throughout the country simultaneously, however, and was not in the hands of the municipalities. We are aware of no other reforms that were introduced in different municipalities at different times and that may be correlated with the introduction of the school reform and with children's outcomes.
} 
Evidence from a Large-Scale Pilot Scheme.” Journal of Human Resources 47(1): 237-269

Hjalmarsson, Randi, Helena Holmlund and Matthew Lindquist. 2011. "The Effect of Education on Criminal Convictions and Incarceration: Causal Evidence from Micro-data." Centre for Economic Policy Research Discussion Paper 8646.

Holmlund, Helena. 2008. "A Researcher's Guide to the Swedish Compulsory School Reform." Centre for the Economics of Education Discussion Paper 087.

Holmlund, Helena, Mikael Lindahl, and Erik Plug. 2008. "The Causal Effect of Parent's Schooling on Children's Schooling: A Comparison of Estimation Methods." Institute for the Study of Labor Discussion Paper 3640.

Lager, Anton Carl Jonas, and Jenny Torssander. 2012. "Causal Effect of Education on Mortality in a Quasi-Experiment on 1.2 million Swedes." Proceedings of the National Academy of Sciences of the United States of America 109 (22): 8461-6.

Marklund, Sixten. 1980. Från reform till reform: Skolsverige 1950-1975, Del 1, 1950 års reformbeslut. Stockholm, Skolöverstyrelsen och UtbildningsFörlaget

Marklund, Sixten. 1981. Från reform till reform: Skolsverige 1950-1975, Del 2, Försöksverksamheten Stockholm: Skolöverstyrelsen och UtbildningsFörlaget.

Marklund, Sixten. 1982. Från reform till reform: Skolsverige 1950-1975, Del 3, Från Visbykompromissen till SIA. Stockholm: Skolöverstyrelsen och UtbildningsFörlaget

Marklund, Sixten. 1985. Från reform till reform: Skolsverige 1950-1975, Del 4, Differentieringsfrågan. Stockholm: Skolöverstyrelsen och UtbildningsFörlaget.

Marklund, Sixten. 1987. Från reform till reform: Skolsverige 1950-1975, Del 5, Läroplaner. Stockholm: Skolöverstyrelsen och UtbildningsFörlaget.

Meghir, Costas, and Mårten Palme. 2003. "Ability, Parental Background and Educational Policy: Empirical Evidence from a Social Experiment.” Institute for Fiscal Studies Working Paper W03/05.

Meghir, Costas, and Mårten Palme. 2005. "Educational Reform, Ability, and Family Background.” American Economic Review 95 (1): 414-24.

Meghir, Costas, Mårten Palme, and Emilia Simeonova. 2012. "Education, Health and Mortality: Evidence from a Social Experiment." National Bureau of Economic Research Working Paper 17932.

Meghir, Costas, Mårten Palme, and Marieke Schnabel. 2012. "The Effect of Education Policy on Crime: An Intergenerational Perspective" National Bureau of Economic Research Working Paper 18145.

SOU 1955:53. Realskolan under övergångstiden. Betänkande avgivet av 
realskoleutredningen. Stockholm, Ecklesiastikdepartementet.

Spasojevic, Jasmina. 2010. "Effects of Education on Adult Health in Sweden: Results from a Natural Experiment." In Contributions to Economic Analysis, 290, ed. Badi H. Baltagi, and Efraim Sadka. 179-99. Bingley: Emerald. 


\section{Appendix B}

This appendix describes the data used for our study. Section III in the paper provides a shorter version of this text.

Our dataset was constructed by integrating registers from Statistics Sweden (SCB) and the Swedish National Service Administration (NSA). The former includes the Census on Population and Housing (Folk- och bostadsräkningen) from 1960, virtually covering the entire Swedish population alive in this year, and the Multi-generation Register (Flergenerationsregistret), allowing us to link parent individuals to (biological) children born during later years. There are also data on educational attainment for 1999, which is expressed in terms of the highest degree attained. On this basis, a standard number of years of schooling has been assigned. The data used for our main analysis include parents with information on educational attainment who were born in Sweden between 1940 and 1957. These cohorts are essentially the ones for which there is variation in terms of whether the reform was implemented or not.

Data on municipality of residence were obtained from the 1960 Census on Population and Housing. Given the information on municipality of residence, we can also assign county of residence in $1960 .^{7}$

The reform assignment is based on an algorithm provided by Helena Holmlund, which is described in Holmlund (2008). ${ }^{8}$ The algorithm uses historical evidence on reform implementation and assigns the reform exposure variable to individuals depending on their year of birth and municipality of residence in 1960. Obviously, individuals need to be in the correct grade according to their age in order for the algorithm to classify them correctly with respect to reform status.

As noted in Appendix A, the reform was implemented for all school districts at the same time in entire municipalities, with the exception of the three big city municipalities, where implementation was more gradual. With the algorithm provided by Holmlund, the implementation cohort in these three cities is only set to one when the entire municipality has transferred to the new system; parishes in these municipalities that are known to have implemented the reform in the earlier years are dropped. Still, it is possible that measurement errors are larger in these three city municipalities compared with the rest of the country

\footnotetext{
${ }^{7}$ A county is an administrative unit comprising a number of municipalities. During the study period of time, Sweden was divided into 25 counties and about 1,000 municipalities.

${ }^{8}$ We are grateful to Helena for generously sharing the reform coding with us.
} 
(Holmlund 2008). In one of our sensitivity checks, we drop these cities.

Data on offspring health and skills were obtained from the military enlistment records, covering males born between 1950 and 1979. We will not use data on individuals from the earlier cohorts, however, since parents have to be born no earlier than 1940 in our main specification. ${ }^{9}$ At the time under study, military enlistment was mandatory for men in Sweden, with exemptions only granted for institutionalized individuals, prisoners, individuals convicted for serious crimes (mostly violence-related and abuse-related crimes), and individuals living abroad. Men usually underwent the military enlistment procedure at the age of 18 or $19 .{ }^{10}$ Refusal to enlist was punishable with a fine, and eventually imprisonment, implying that the attrition in our data is very low; only about 3 percent of each cohort of males did not enlist.

\section{A. Outcome Variables}

Our analysis uses several different measures of individuals' overall health status which are available in the military enlistment data. First, depending on the conscript's health conditions and their severity, the NSA indicated the conscript's overall health status on a 14-step scale, which was used to determine the individual's suitability with respect to type of military service. As our first measure of overall health, which we will refer to as 'global health' we assign a variable equaling zero to individuals belonging to the most healthy category, minus one to those belonging to the second most healthy category, etc., and we then normalize this variable to have standard deviation one. ${ }^{11}$ For ease of interpretation and comparison, all the non-binary outcome variables used in our analysis are normalized to have zero mean and standard deviation one. ${ }^{12}$

The assessment of individuals' health that underlies the assignment of the global health variable is based on a health declaration form that the individual filled in at home and had to bring with him, combined with a general assessment of the individual's health lasting for

\footnotetext{
${ }^{9}$ Also, the children had to live in Sweden during 1999 since the enlistment information was initially collected for the 1999 population data.

${ }^{10}$ According to our data, 80 percent of all individuals enlisted during the year they turned 18 , whereas 18 percent did so during the year they turned 19. Virtually no individuals enlisted before the age of 18 .

${ }^{11}$ In Lundborg, Nilsson and Rooth (2011) we showed that this measure of global health strongly predicts adult incomes in a sample of siblings and twins.

${ }^{12}$ In our analysis, we also try an indicator for being in 'poor health' as an alternative to the 14-step scale. This indicator corresponds to the last two steps on the scale.
} 
about 20 minutes, performed by a physician. Before meeting with the physician, the individual underwent a number of physical capacity tests and met with a psychologist who, if necessary, could provide the physician with notes regarding the individual's mental status. Any health problem, present or historic, that may interfere with the individual's ability to undergo military service is supposed to be reflected in our measure of overall health status. The individual was expected to bring any doctor's certificate, health record, drug prescription or similar proving that he actually suffered from the conditions he reported in his health declaration.

The incentives to cheat and, for instance, underreport one's health, were most likely limited since almost everyone was required to undergo military service during the study period. Underreporting one's health would thus not affect the probability that one had to undergo military service. Cheating was also difficult, since health status was not simply self-reported, but also based on obligatory assessments and doctor's certificates. This means that measurement errors from, for example, differences in health-seeking behaviors or in health awareness, which may be present in sources like hospital and insurance records or standard self-evaluations, should be less of an issue. ${ }^{13}$

As an alternative measure of overall health, we use height, as determined at military enlistment. An adult's height relates to many aspects of their childhood health status (e.g., Bozzoli, Deaton and Quintana-Domeque 2009) and has been referred to as 'probably the best single indicator of his or her dietary and infectious disease history during childhood' (Elo and Preston 1992). Moreover, height among Swedish males, as measured at the Swedish enlistment, has been found to relate to adult earnings (Lundborg, Nystedt and Rooth 2013). It has also been documented that children of parents with more years of education tend to be taller (e.g., Thomas 1994), although it is not clear if this relationship reflects a causal effect.

In addition to height, we make use of three different physical test variables from the military enlistment records, which relate to certain dimensions of individuals' health and capacities. First of all, we make use of physical work capacity, measured as the maximum

\footnotetext{
${ }^{13}$ Still, if health or other outcomes for some reason are measured with error in our data, estimates may be biased if these errors are also related to parental education. If for instance individuals with low-educated parents underreport their health or abilities to a greater extent, our estimates would be upward biased. Conversely, if individuals with high-educated parents underreport their health or abilities, our estimates would be downward biased. It is not clear to us why either of these groups would have any strong incentive to misreport, since lower reported health or skills typically would lead to a less qualified placement in the army and since lower reports would not affect the probability of doing military service.
} 
number of watts attained when riding on a stationary bike (for about five minutes) divided by weight in kilograms. Measures of this type are often referred to as Maximum Working Capacity and have consistently been associated with lowered risk of premature deaths from mainly cardiovascular diseases and to a lesser extent with lowered risk of cancer-related mortality (Ekelund et al. 1988; Slattery and Jacobs 1988; Blair et al. 1989; Sandvik et al. 1993). ${ }^{14}$ The measure is closely related to maximum oxygen uptake $\left(\mathrm{VO}_{2} \mathrm{max}\right)$, which has been labeled as 'the single best measure of cardiovascular fitness and maximal aerobic power' (Hyde and Gengenbach 2007). A large number of studies have found a positive relationship between parents' education and child or adolescent physical activity (Stalsberg and Pedersen 2010), which, if causal, would also suggest that more parental education may lead to a higher physical capacity of their children.

Second and third, we include indicators of obesity and hypertension. Using standard definitions, we classify individuals as obese if their BMI $\left(\mathrm{kg} / \mathrm{m}^{2}\right)$ is higher than or equal to 30 and as hypertensive if either their systolic blood pressure is higher than or equal to $140 \mathrm{mmHg}$ or their diastolic blood pressure is higher than or equal to $90 \mathrm{mmHg}$. Both obesity and hypertension are well-known risk factors of diseases such as cardiovascular diseases and diabetes (e.g., Sowers, Epstein and Frohlich 2001; Poirier et al. 2006). Obesity can also lead to discrimination in the labor market (e.g., Lundborg, Nystedt and Rooth 2010). It has been documented that children of parents with more years of education tend to have lower incidences of obesity and hypertension (e.g., Coto et al. 1987; Lamerz et al. 2005).

We also include measures of cognitive and non-cognitive ability. Cognitive ability is measured by written tests of logical, verbal, spatial and technical skills. Based on these test scores, the individual is assigned a number on a nine-point scale, approximating a normal distribution, which we normalize to have standard deviation one.

In a similar way, non-cognitive ability is also measured on one to nine cale, which we normalize to have standard deviation one. This score is assigned by a psychologist, based on a semi-structured interview lasting for about 25 minutes, whose objective is "to assess the conscript's ability to cope with the psychological requirements of the military service and, in extreme case, war" (Lindqvist and Vestman 2011). This in particular implies an assessment of personal characteristics such as willingness to assume responsibility, independence, outgoing character, persistence, emotional stability and power of initiative. In addition, an important

\footnotetext{
${ }^{14}$ Moreover, Rooth (2011) found that physical capacity (as measured at the Swedish military enlistment) has positive effects on subsequent labor market outcomes in terms of higher earnings.
} 
objective of the interview is to identify individuals considered particularly unsuited for military service, such as those with antisocial personality disorders, those with difficulty accepting authority, those with difficulties adjusting to new environments and those liable to violent and aggressive behavior (Andersson and Carlstedt 2003; Lindqvist and Vestman 2011).

\section{B. Sample Construction}

Our main estimation sample was constructed by imposing the following restrictions. For the child generation, we excluded the small number of women ( 0.25 percent) who volunteered for the military. Next, for the parent generation, we obviously had to exclude all individuals not having a son being observed in the enlistment records (39 percent). This restriction implies that parents who have children at earlier ages are somewhat overrepresented in our sample, since no children born after 1979 were observed in our data. Parents with missing data on municipality of residence were then excluded ( 1 percent), and of the remaining parents, individuals in municipalities for which the algorithm was unable to assign reform status were also excluded (11 percent). Moreover, in order to avoid short-run adjustment effects of the reform as well as misclassification of individuals born right around the implementation cohorts, we excluded individuals belonging to the first reform cohort, and the cohorts immediately preceding and following it (14 percent). Finally, considering only children for whom at least one parent was observed in the sample, our estimation sample included 503,768 individuals in the child generation. For 405,845 of these, their mother was observed in the estimation sample, and for 326,600 their father was observed. The reason why the number of children for whom a father was observed is smaller than the number of children for whom a mother was observed is partly because fathers are generally older than mothers and are thus more likely to have been born before the start of our sample period, and partly because SCB has in some cases not been able to link individuals to their biological fathers.

\section{REFERENCES}

Andersson, Jens, and Berit Carlstedt. 2003. Urval till Plikttjänst. Karlstad: Försvarshögskolan.

Blair, Stephen N., Harold W. Kohl, Ralph S. Paffenberger, Jr., Debra G. Clark, Kenneth H. Cooper, and Larry W. Gibbons. 1989. "Physical Fitness and All-Cause Mortality. A Prospective Study of Healthy Men and Women.”JAMA, 262 (17): 2395-401.

Bozzoli, Carlos G., Angus S. Deaton, and Climent Quintana-Domeque. 2009. “Adult Height 
and Childhood Disease.” Demography 46 (4): 647-69.

Coto, Vincenzo, Antonio Luciariello, Manlio Cocozza, Ugo Oliveriero, and Luigi Cacciatore. 1987. "Socioeconomic Status and Hypertension in Children of Two State Schools in Naples, Italy: Preliminary Findings.” European Journal of Epidemiology, 3 (3): 288-94.

Ekelund, Lars-Göran, William L. Haskell, Jeffrey L. Johnson, Fredrick S. Whaley, Michael H. Criqui, and David S. Sheps. 1988. "Physical Fitness as a Predictor of Cardiovascular Mortality in Asymptomatic North American Men: The Lipid Research Clinics Mortality Follow-up Study." New England Journal of Medicine 319 (21): 1379-84.

Elo, Irma.T., and Samuel H. Preston. 1992. "Effects of Early-Life Conditions on Adult Mortality: A Review." Population Index 58 (2): 186-212.

Holmlund, Helena. 2008. “A Researcher's Guide to the Swedish Compulsory School Reform." Centre for the Economics of Education Discussion Paper 087.

Hyde, Thomas E., and Marianne S. Gengenbach. 2007. Conservative Management of Sports Injuries. Sudbury, MA: Jones and Bartless Publishers.

Lamerz, Andreas, Jutta Kuepper-Nybelen, Christine Wehle, Nicole Bruning, Gabriele TrostBrinkhues, Hermann Brenner, Johannes Hebebrand, and Beate Herpertz-Dahlmann. 2005. "Social Class, Parental Education, and Obesity Prevalence in a Study of Six-Year-Old Children in Germany.” International Journal of Obesity 29 (4): 373-80.

Lindqvist, Erik, and Roine Vestman. 2011. "The Labor Market Returns to Cognitive and Noncognitive Ability: Evidence from the Swedish Enlistment." American Economic Journal: Applied Economics 3 (1): 101-28.

Lundborg, Petter, Anton Nilsson, and Dan-Olof Rooth. 2011. "Early Life Health and Adult Earnings: Evidence from a Large Sample of Siblings and Twins". Institute for the Study of Labor Discussion Paper 5804.

Lundborg, Petter, Paul Nystedt, and Dan-Olof Rooth. 2010. "No Country for Fat Men? Obesity, Earnings, Skills, and Health among 450,000 Swedish Men.” Institute for the Study of Labor Discussion Paper 4775.

Lundborg, Petter, Paul Nystedt, and Dan-Olof Rooth. 2013. "Height and Earnings. The Role of Cognitive and Non-Cognitive Skills. Forthcoming in Journal of Human Resources.

Poirier, Paul, Thomas D. Giles, George A. Bray, Yuling Hong, Judith S. Stern, F. Xavier PiSunyer, and Robert H. Eckel. 2006. "Obesity and Cardiovascular Disease: Pathophysiology, Evaluation, and Effect of Weight Loss." Circulation 113 (6): 898-918.

Rooth, Dan-Olof. 2011. "Work Out or Out of Work - The Labor Market Return to Physical Fitness and Leisure Sports Activities.” Labour Economics (18) 3: 399-409. 
Sandvik, Leiv, Jan Erikssen, Erik Thaulow, Gunnar Erikssen, Reidar Mundal, and Kaare Rodahl. 1993. "Physical Fitness as a Predictor of Mortality Among Healthy, Middle-Aged Norwegian Men.” New England Journal of Medicine 328 (8): 533-7.

Slattery, Martha L., and David R. Jacobs, Jr. 1988. "Physical Fitness and Cardiovascular Disease Mortality: The US Railroad Study.” American Journal of Epidemiology 127 (3): 571-80.

Sowers, James R., Murray Epstein, and Edward D. Frohlich. 2001. "Diabetes, Hypertension, and Cardiovascular Disease: An Update." Hypertension 37 (4): 1053-9.

Stalsberg, Ragna, and Are V. Pedersen. 2010. "Effects of Socioeconomic Status on the Physical Activity in Adolescents: A Systematic Review of the Evidence." Scandinavian Journal of Medicine \& Science in Sports 20 (3): 368-83.

Thomas, Duncan. 1994. "Like Father, Like Son; Like Mother, Like Daughter: Parental Resources and Child Height.” Journal of Human Resources 29 (4): 950-88. 


\section{Appendix C}

TABLE C1-WEIGHTS FOR IV AND FOR TWIN FE ESTIMATES

\begin{tabular}{lcccc}
\hline \hline & \multicolumn{2}{c}{ IV WEIGHTS } & \multicolumn{2}{c}{ TWIN FE WEIGHTS } \\
$\begin{array}{l}\text { Years of } \\
\text { schooling }\end{array}$ & $\begin{array}{c}\text { Mother's } \\
\text { education }\end{array}$ & $\begin{array}{c}\text { Father's } \\
\text { education }\end{array}$ & $\begin{array}{c}\text { Mother's } \\
\text { education }\end{array}$ & $\begin{array}{c}\text { Father's } \\
\text { education }\end{array}$ \\
7 to 9 & 0.807 & 0.868 & 0.281 & 0.259 \\
9 to 11 & 0.127 & 0.083 & 0.351 & 0.313 \\
11 to 12 & 0.011 & 0.024 & 0.099 & 0.114 \\
12 to 14 & 0.005 & 0.016 & 0.178 & 0.185 \\
14 to 16 & 0.036 & 0.001 & 0.089 & 0.118 \\
16 to 20 & 0.013 & 0.008 & 0.001 & 0.112
\end{tabular}

Notes: The table shows the weights that the IV and twin FE estimators attach to the marginal effects of parental education across the education distribution. The calculations are based on the formulas provided by Løken, Mogstad and Wiswall (2012), where we use their OLS formula and enter the fixed effects as dummies when calculating the twin FE weights. We have used the sample of individuals with non-missing data on cognitive ability; calculations using individuals with non-missing data kon other outcome variables produce essentially the same results and are available from the authors upon request. 


\begin{tabular}{lccc}
\hline \hline & $\begin{array}{c}(1) \\
\text { Parent's } \\
\text { log income }\end{array}$ & $\begin{array}{c}(2) \\
\text { Parent's income } \\
\text { expressed in SEK }\end{array}$ & $\begin{array}{c}(3) \\
\text { Total income of the } \\
\text { couple (SEK) }\end{array}$ \\
Years of & 0.006 & 575 & $2,012^{* * *}$ \\
Schooling & $(0.019)$ & $(304)$ & $(660)$ \\
N & 1,740 & 1,928 & 1,928 \\
Father & & & $1,301^{* *}$ \\
Years of & $0.012^{*}$ & 496 & $(647)$ \\
schooling & $(0.006)$ & $(455)$ & 1,245 \\
N & 1,233 & 1,245 &
\end{tabular}

Notes: The table shows parental returns to schooling, for parents who are monozygotic twins, when controlling for twin-pair fixed effects. Each estimate represents the coefficient from a different regression.

$* * *$ Significant at the 1 percent level.

** Significant at the 5 percent level.

* Significant at the 10 percent level. 


\section{Appendix D}

TABLE D1—EXCLUding PARENT INDIVIDUALS ThAT HAVE LEFT SCHOOL BY 1960

\begin{tabular}{lccccccc}
\hline \hline & $\begin{array}{c}(1) \\
\text { Global } \\
\text { health }\end{array}$ & $\begin{array}{c}(2) \\
\text { Height }\end{array}$ & $\begin{array}{c}(3) \\
\text { Physical } \\
\text { capacity }\end{array}$ & $\begin{array}{c}(4) \\
\text { Obesity }\end{array}$ & $\begin{array}{c}(5) \\
\text { Hyper- } \\
\text { tension }\end{array}$ & $\begin{array}{c}(6) \\
\text { Cognitive } \\
\text { ability }\end{array}$ & $\begin{array}{c}\text { Non- } \\
\text { cognitive } \\
\text { ability }\end{array}$ \\
Mother & & & & & & & \\
Years of & 0.070 & $0.079 *$ & -0.001 & -0.007 & 0.028 & $0.097 * *$ & 0.065 \\
schooling & $(0.050)$ & $(0.046)$ & $(0.049)$ & $(0.007)$ & $(0.019)$ & $(0.042)$ & $(0.046)$ \\
N & 291,575 & 280,434 & 257,973 & 280,429 & 275,584 & 281,607 & 266,786 \\
Father & & & & & & & \\
Years of & 0.014 & -0.047 & 0.066 & -0.005 & 0.019 & -0.030 & 0.027 \\
schooling & $(0.046)$ & $(0.044)$ & $(0.052)$ & $(0.007)$ & $(0.016)$ & $(0.047)$ & $(0.046)$ \\
N & 220,689 & 212,186 & 191,723 & 212,183 & 208,119 & 212,936 & 201,036
\end{tabular}

Notes: Regressions are run with robust standard errors that are clustered at the municipality level.

*** Significant at the 1 percent level.

** Significant at the 5 percent level.

* Significant at the 10 percent level. 


\section{Appendix E}

TABLE E1-ADDING PARENT INDIVIDUALS BORN 1934-1939

$\begin{array}{ccccccc}(1) & (2) & (3) & (4) & (5) & (6) & (7) \\ \begin{array}{l}\text { Global } \\ \text { health }\end{array} & \text { Height } & \begin{array}{l}\text { Physical } \\ \text { capacity }\end{array} & \text { Obesity } & \begin{array}{c}\text { Hyper- } \\ \text { tension }\end{array} & \begin{array}{c}\text { Cognitive } \\ \text { ability }\end{array} & \begin{array}{c}\text { Non- } \\ \text { cognitive } \\ \text { ability }\end{array}\end{array}$

Panel A. With municipality-specific linear trends

\begin{tabular}{|c|c|c|c|c|c|c|c|}
\hline $\begin{array}{l}\text { Mother's } \\
\text { schooling }\end{array}$ & $\begin{array}{c}0.082 * * * \\
(0.029)\end{array}$ & $\begin{array}{c}0.061 * * \\
(0.030)\end{array}$ & $\begin{array}{c}0.073 * * \\
(0.032)\end{array}$ & $\begin{array}{c}-0.002 \\
(0.004)\end{array}$ & $\begin{array}{c}-0.002 \\
(0.010)\end{array}$ & $\begin{array}{c}0.117 * * * \\
(0.026)\end{array}$ & $\begin{array}{r}0.067 * * \\
(0.032)\end{array}$ \\
\hline Father's & 0.014 & -0.010 & 0.036 & -0.003 & $0.027 * *$ & -0.003 & 0.011 \\
\hline schooling & $(0.030)$ & $(0.029)$ & $(0.033)$ & $(0.004)$ & $(0.011)$ & $(0.029)$ & $(0.032)$ \\
\hline \multicolumn{8}{|c|}{ Panel B. With municipality-specific quadratic trends } \\
\hline Mother's & $0.082 * *$ & 0.045 & $0.064 *$ & -0.004 & 0.005 & $0.130 * * *$ & $0.066^{*}$ \\
\hline schooling & $(0.038)$ & $(0.037)$ & $(0.037)$ & $(0.006)$ & $(0.013)$ & $(0.036)$ & $(0.039)$ \\
\hline Father's & 0.026 & -0.052 & 0.052 & -0.004 & $0.048 * * *$ & -0.032 & 0.036 \\
\hline schooling & $(0.040)$ & (0.039) & $(0.043)$ & $(0.006)$ & $(0.015)$ & $(0.041)$ & $(0.041)$ \\
\hline Mothers & 576,770 & 558,438 & 530,011 & 558,387 & 577,244 & 560,782 & 538,967 \\
\hline Fathers & 482,232 & 465,933 & 439,193 & 465,895 & 483,035 & 467,902 & 447,546 \\
\hline
\end{tabular}

Notes: Each estimate represents the coefficient from a different regression. Regressions are run with robust standard errors that are clustered at the municipality level.

*** Significant at the 1 percent level.

** Significant at the 5 percent level.

* Significant at the 10 percent level. 